\title{
Retraction Note: therapeutic stimulation of GLP-1 and GIP protein with DPP-4 inhibitors for type-2 diabetes treatment
}

\author{
Alok Sharma*, Geetanjali Paliwal, Nisha Upadhyay and Archana Tiwari
}

The Editors are retracting this article [1] due to overlap with previous publications, most notably [2, 3]. We apologise for any inconvenience caused. We have been unable to contact the authors regarding the retraction of their article.

Received: 5 August 2016 Accepted: 11 August 2016

Published online: 30 August 2016

\section{References}

1. Sharma A, Paliwal G, Upadhyay N, Tiwari A. Therapeutic stimulation of GLP-1 and GIP protein with DPP-4 inhibitors for type-2 diabetes treatment. J Diab Metabol Disord. 2015;14:15.

2. Drucker DJ. Enhancing incretin action for the treatment of type 2 diabetes. Diabetes Care. 2003;26:2929-40.

3. Kountz D. The dipeptidyl peptidase (DPP)-4 inhibitors for type 2 diabetes mellitus in challenging patient groups. Adv Ther. 2013;30:1067-85.

\footnotetext{
*Correspondence: alokmolbio@yahoo.com

The online version of the original article can be found under doi:10.1186/ s40200-015-0143-4.

School of Biotechnology, Rajiv Gandhi Proudyogiki Vishwavidyalaya (State Technological University of Madhya Pradesh), Bhopal, India
}

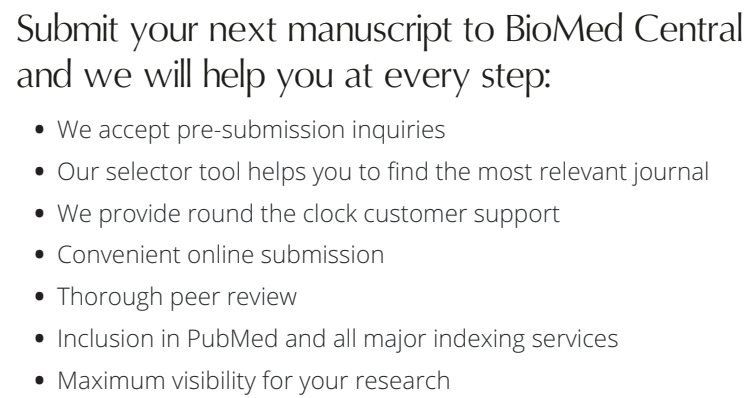
and we will help you at every step:

- We accept pre-submission inquiries

- Our selector tool helps you to find the most relevant journal

- We provide round the clock customer support

- Convenient online submission

- Thorough peer review

- Inclusion in PubMed and all major indexing services

- Maximum visibility for your research

Submit your manuscript at www.biomedcentral.com/submit 